\title{
Leadership, Strategic Communication and National Security in Nigeria
}

\author{
Loveday Enyinnaya Ogbuleke ${ }^{1} \&$ Nicholas Idris Erameh ${ }^{2}$ \\ ${ }^{1}$ Department of Peace and Conflict Resolution Studies, College of Arts, Law, Administration and Management Sciences, Legacy \\ University, The Gambia. \\ ${ }^{2}$ Department of Political Science and International Relations, Chrisland University, Abeokuta, Ogun State, Nigeria.
}

DOI: $10.46382 / M J B A S .2020 .4205$

This study interrogates the place of leadership and strategic communication in the actualization of overall national security in Nigeria. These tools of communication have been used to both incite violence as well as carry messages that help prevent violent conflict, and promote peace and reconciliation and Nigerian military is not exceptional. For instance, countering the Boko Haram insurgency was psychological operations. The Army was more successful in using this approach when Boko Haram's use of violence was at its peak. Details for this are not hard to decipher, though they have never publicly explained why they engaged in psychological operations nor have they even admitted using them. There was a collective fear then, even among journalists and media establishments, some of whom were victims of Boko Haram's attacks. The support the security services received from the media might have come from the need to address this for lasting solution in the nearest future. Due to government negligence on strategic communicate for national security, these gaps have unavoidably resulted in the resilience and devastating consequences in the state. Therefore, there is need for leaders to integrate a new culture of communication among agencies which can leads to greater efficiency in information and intelligence sharing under the established Strategic Communication Inter - Agency Policy Coordination Committee in overseeing strategic communication for national security.

Keywords: Leadership, Strategic Communication, National Security, Mass Media, and National Development.

\section{Introduction}

The control and management of information is central to a successful warfare or maintaining a condition of peace in this digital age (Awosusi and Ogbuleke, 2019). A sustainable national development is a function of national security which is hinge on the quality of information available and manner upon which such information is controlled (ibid). Thus the place strategic communication plays in conflict and post-conflict scenarios cannot be underemphasized. The use of traditional or mass media (radio, TV, print journalism) has long been acknowledged as playing a crucial part in providing information and messaging that can shape popular views. Over the years, these tools of communication have been used to both incite violence as well as carry messages that help prevent violent conflict, and promote peace and reconciliation. Technological innovations have created new opportunities and outlets for communication (Diane and Meier 2009).

Furthermore, the advent of global terrorism has added new dimension to conflict within the international order. According to Imran et al (2012), the international security landscape has become more volatile, complex and ambiguous, shaped by increasing transnational threats from activities of violent extremist organizations. The prevalence of small arms and light weapons through smuggling and the ease of acquiring knowledge for improvised 
explosive devices have further emboldened criminal and terrorist networks in their violent activities within and across nations. As a result of the global war on terrorists, the use of military approaches for advancing national security policies is becoming less attractive especially due to compromising in strategic communication.

According to Williams (2017), strategic communications is not propaganda, nor psychological operations, nor information ops, nor spin-all of which involve an intention to mislead in some way. Strategic communications is about strategic impact through credible narrative. In complex situations, where reasonable people can hold different views or see the problem from different angles, strategic communications is an honest attempt to frame the way people around the world understand what is at stake (ibid).

The rising of insecurity have inclined the Nigerian government (military) to involved in internal security operations, primarily because of several security threats across the country, such as Boko Haram insurgency in the North east, Cattle rustling and armed bandits in the North west, secessionist agitation and armed robbery in the South east and militancy and oil bunkering in the south-south, that have overwhelm the Police and other security agencies (Awosusi and Ogbuleke, 2019).

In the fight against Boko Haram insurgents is a major lapse in the Nigerian government and the Army's counter-insurgency efforts (Abubakar, 2017). On numerous occasions the military would issue half-truths or untruths that were easily punctured by the militants or simply detected by the public (ibid). Their repeated claims of Shekau's death, for instance, were effectively countered by the insurgents with simple releases of their leader's video and audio recordings to prove that he was still alive and unharmed in many occasions. Each successful rebuttal of such claims erodes the credibility of the Army and enhances that of the jihadists (ibid).

Therefore, the use of strategic communication by government to protect its interests and citizens becomes a key weapon of defence, thus requiring that a nation evolves her strategic communications framework to enhance the security and resilience of her citizens. The overarching objective of Nigeria's strategic communications is to provide the framework for organization, processing and dissemination of information to influence the citizens and change their behaviour positively towards securing unity, cohesion and development. Against these backdrops this paper assesses the nature of strategic communication in managing national security in Nigeria in which we realize the social, moral, and organizational importance of security and the need to coordinate and collective manage 
security efforts in order for security to unfold its beneficial capabilities (Awosusi and Ogbuleke, 2019).

\section{Objectives of the Research}

The main objective of the study is to assess how Nigerian leaders engage in strategic communication in managing national security and the extent which it have affected socio-economic development of the nation. Specific objectives are as follows:

To identify the major reasons leaders engage in strategic communication for national security.

To ascertain the extent to which Nigerian leaders engage in strategic communication for national security.

To reveal the implications of lack of strategic communication on national security.

\section{Justification for the Study}

The study of this nature becomes imperative in that it is conceived to serve as an eye opener to the leaders who might be able to ascertain the significance of strategic communication leadership, and the study also have the potential of serving as a guide to researchers who might be working on the areas of deficiencies of leaders in Nigeria in order to improve on leadership traits with a view to having a sustainable national development.

\section{Conceptual Clarification}

Three key concepts that need to be analyzed are those of 'leadership', 'strategic communication' and 'national security', "leadership is the management task that is concerned with how to influence the behaviour of subordinates" (Oyedijo, 1995). Therefore, to optimize the utilitarian value of the "organizational personnel" requires providing leadership, especially in an ever-changing environment where planning and periodic review of plans become imperative.

\section{Leadership}

Leadership is a process by which a person influences others to accomplish an objective and directs the organization in a way that makes it more organized and logically meaningful to the society. Leadership is a process whereby an individual influences a group of individuals to achieve a common goal for particular given time or period. A leader's capacity to influence people in order unleashing their power and potential to impact the greater good act does not necessarily come from special powers. And it is more often comes from a strong belief in a purpose and willingness to pursue that conviction. In addition, a leader must have the 
courage to accept the risks associated with the struggle to attain organizational goals, and the skills to develop a consensus (Aibieyi, 2014; Blanchard 2010).

Sorenson and Epps (1996) define leadership as a process by which forceful and dynamic personality of one who leads from the front; an architect and implementer of strategy; a mediator in conflict situations; an integrator who assures the climate of the organization; a person able to motivate subordinates and who, by persuasion, compulsion or example to others; succeeds in getting others to follow the leader's wishes. These views provide some of the desired characteristics of leadership. However, it did not make provision for the stakeholders responsible for the strategic communication to reposition leadership and how it could be carried out with a view to achieving national security.

According to Aibieyi S (2014), leadership displays the quality of behaviour of an individual in guiding people or their activities in organized effort. It also includes process of exhibiting personal qualities of the leader to influence workers to voluntarily comply with all working principles of the organization. This view covers the key stakeholders involved in the application of leadership and provides the desired characteristics for linkages with communication. It is thus, the most viable option for this paper and so adopted.

For this paper, leadership is a complex process by which a person influences others to accomplish a mission, task, or objective and directs the organization in a way that makes it more unified. A person carries out his process by applying her leadership attributes (belief, values, ethics, character, knowledge, and skills). However, to conceptualize political leadership therefore entails immense disputations. But in this study, political leadership is simply conceived as that strand of leadership that is provided by elected politicians, entrusted with the task of national development. It is consequently suggested in this paper that a key function of political leadership, in the context of a nation state, is to continuously reconcile competing ethnic interests and ethnic contentions for national security.

\section{Strategic Communication}

The term strategic communication meant different things to different people at various times. in a real-time worldwide information system is a branch of the art of war comparable to logistics or intelligence which require staffing, educating and practicing at about the same level of resources as intelligence or logistics to be successful (Castells, 2008; James, 2007). This view presents a meaning of strategic communication which is the process of something being used-up by different people at particular given time or period. The Public Affairs Operations USA explains it in these words; Western scholars claim that during times of 
major conflict, strategic communication has a crucial role. Some military experts argue that strategic communication, in irregular warfare, is the campaign rather than an aspect of it (Thomas, 2007). In the field of leadership and strategic communication for instance, it does not indicate any major reasons leaders engage in strategic communication for national security. These view does not fit the context of this study and is therefore, not considered further.

Strategic communication has been defined as the study of how organizations use communication purposefully to fulfill their overall missions (Frandsen and Johansen, 2017). The aim of strategic communication as an academic movement has been formulated as an ambition to break down the silos surrounding closely related communication disciplines and create a unifying framework that integrates public relations, organizational communication, marketing communication and other areas. The fundamental idea of strategic communication is thus inclusive, which is a laudable ambition. This view focuses on broad scope of the field is also a challenge because it requires research to break away from established disciplines and fields of knowledge, thus allowing for novel approaches and questions to be explored (Holtzhausen and Zerfass, 2015). This view is not suitable for this paper and therefore, not adopted.

Hammes (2005) suggests that modern insurgencies have become a strategic communication campaign supported by military action. This view gives an in-depth paradigm shift from the traditionally accepted method of conducting operations, which employs public diplomacy and other related instruments in support of military operations. Strategic Communication, which is both message and action, provides the means to harness the elements of national power in an effective manner. The above-mentioned orchestra helps us to understand strategic communication as coordination of statecraft, Public Affairs, Public Diplomacy (Military), Information Operations and other activities, reinforced by political, economic and military actions, in a synchronized and coordinated manner. This view aligns with the focus of this paper and it is therefore adopted.

\section{National Security}

The term security is a significant concept and issue that connotes many meanings to intellectuals and practitioners. Its meanings ambiguous with its scope expanding every day, in which food security, economy security, personal, national security among others are embedded its. According to William (2008) security is associated with the alleviation of threats to cherished values. For a nation, security connotes conditions of peace, stability, 
order and progress. National security has been construed in different ways, each of which emphasized vital factors underlying ideals (Awosusi and Ogbuleke, 2019).

Thus, Shinkaye (2004) opines that national security is the protection of a nation from all types of external aggression, espionage, hostile, reconnaissance, sabotage, subversion, annoyance and other inimical influences. This definition views national security traditionally as referring to the protection of the territorial integrity of a state and the protection of its citizens from external threats, with specific focus on protection against military attack. The notion of national security has in contemporary times gone beyond protection not just from external and internal threats, but also threats to a state's way of life.

In Bellamy (1991) view, national security is the relative freedom from war coupled with relatively high expectation that defeat will not be a consequence of any war that should occur. This definition provides a basic understanding of national security but is narrowed to security related to external threats or high intensity conflicts and fails to consider the human elements that pose threats to the wellbeing of the citizens and security of lives and property in a nation. However, strategic communication helps to influence perception of the target audience. Therefore, planning and implementing national security objectives requires deliberate employment of all elements of strategic communications to effectively inform, educate, persuade, influence and coordinate efforts of the state, agencies and the citizenry.

\section{Transformational Theory}

Transformational leadership theory has been the most studied and debated leadership theory among scholars over the years. A transformational leader is one who raises the level of consciousness of his followers about the importance and value of outcome and the methods of reaching those outcomes (Burns, 1978). In Berkovich (2016) assertion, a transformational leader uses his charisma to coach, mentor, and challenge and support followers to transcend their own self-interests for that of the organization (Bass 2008).

Transformational leadership distinguishes itself from the rest of the previous and contemporary theories, on the basis of its alignment to a greater good as it entails involvement of the followers in processes or activities related to personal factor towards the organization and a course that will yield certain superior social dividend. By emphasizing the importance of safety and exhibiting idealized behaviors, these leaders tend to increase subordinates' safety awareness and instill in their subordinates the belief that safety is a shared common goal (Lixin and Tahira, 2016). The transformational leaders raise the motivation and morality of both the follower and the leader (House and Shamir, 1993). As 
such, subordinates are likely to engage in more safety participation as an avenue for reciprocation. Indeed, a positive relationship between transformational leadership and safety participation has been consistently established (Clarke, 2013).

Despite critics of transformational leadership state that there is no clear indications/fundamental models of the effects on this theory on organizational outcomes (Van Knippenberg and Sitkin, 2013). This theory conforms by the Maslow (1954) higher order needs theory. The literature suggests that followers and leaders set aside personal interests for the benefit for the national development of the state or group. Therefore, if Nigerian government or leaders possess the attributes of transformation leadership theory, strategic communication would have be collective task with the followers. These types of leaders treat subordinates individually and pursue to develop their consciousness, morals and skills by providing significance to their work and challenge. These leaders produce an appearance of convincing and encouraged vision of the future. They are "visionary leaders who seek to appeal to their followers" better nature and move them toward higher and more universal needs and purposes" (MacGregor Bums, 2003).

The adoption of transformation leadership theory aimed at shifting government perception that national security is an exclusive duty without involving the followership. The Transformation Leadership Theory is applicable to this study in the sense that it emphasizes changes and approach targets on beliefs, values and attitudes that enlighten leader's practices and the capacity to lead change. In this, the introduction of the transformation leadership in Nigeria finds its basis for enhanced strategic communication for national security.

\section{The Nigerian State, Strategic Communication and National Security}

The history of strategic communication in Nigeria can be dated back when the national security organisation was created under Decree 27 of 1976 under the military regime of Gen Olusegun Obasanjo after failed Dinka Coup which led to the death of former Head of State Gen Murtala Mohammed, and the mandate of the organisation to co-ordinate internal security, foreign intelligence, and counterintelligence.

Since then, strategic communication has been Nigerian government systemic approach to protection and prevention for any crime against the security of the state. The overarching objective of strategic communications efforts for our national security is to coordinate government wide communication activities to counter the appeal of violent extremism while promoting Nigeria's national core values (Cornish, 2011). Winning the confidence and 
goodwill of citizens in communities affected by the insurgency is an important asset to both the armed forces and the insurgents, making their hearts and minds a battleground in itself. Abubakar (2017) argues that the Army's unconventional approach to communicating with the mainstream media was anchored on the desire to manage the security challenges created by Boko Haram's violence. Military officials use their contacts with the media to persuade editors to suppress stories they deem inimical to national security (Ibid). This approach does not involve using threat or intimidation; rather it relies on moral suasion and appealing to journalists' sense of patriotism to make them handle issues in a way that is helpful to the Army's counter-insurgency mission (Ibid).

The Army was more successful in using this approach when Boko Haram's use of violence was at its peak. There was a collective fear then, even among journalists and media establishments, some of whom were victims of Boko Haram's attacks.

The support the security services received from the media might have come from the need to address this. There was confirmation that the security services did receive this support. We received massive and unprecedented support from the local and foreign media for the accomplishment of our nation in the war on terror (cited in The Nation, 2017).

The other approach the Nigerian Army employed in countering the Boko Haram insurgency was psychological operations. Details for this are hard to decipher, but the Army's former media consultant admitted that it was part of their strategy. The extent to which the Army has engaged in psychological operation is difficult to know, and that is the nature of Psychological Operations (PsyOps). They have never publicly explained why they engaged in psychological operations nor have they even admitted using them. There are debates over the inclusion of PsyOps in strategic communications. Security expert James Farwell argues that PsyOps aim at influencing and shaping audiences' behaviour the key objectives of strategic communications (Asaju, 2015).

The risk usually lies in the public uncovering the truth which they sometimes do and losing their trust. Being caught lying is costlier for the Nigerian Army than for Boko Haram because the public regard the group as an outcast and do not always expect honesty from its members. Ironically, as noted earlier, on many occasions Boko Haram gave more credible accounts of events than the Army did. And this has dented the Army's strategic communications campaigns. However, there is an area where they are making progress digital engagement though there, too, it was the jihadists who made the first move (Daily Trust, 2015). 


\section{Challenges of Strategic Communication and National Security in Nigeria}

As Nigeria moves to entrench its strategic communications strategies across government agencies, there are some challenges that should be envisaged and considered for remedies to avoid pitfalls of previous similar government initiatives often faces challenges in the form of power supremacy among security agencies, weak technical skills, poor professional journalistic standards and dearth financial resources. Others include power and control, ownership of the process, cultural and social norms and uptake by individual and societies. Thus, Nigeria needs committed leaders who will govern with integrity and doggedly influence its human and natural resources toward the actualization of sustainable national development (Omorogbe, Oladele, Imhonopi and Evbuoma, 2016).

Thus, Eme, (2018), buttressed that eradicating insurgency in any polity is a wishful thinking just like evaluating the success or failure of the counter- insurgency strategies. Expectedly, these gaps have unavoidably resulted in the resilience and devastating consequences of inter-security agency rivalry. For instance, apart from the deterioration of insecurity and threats to peace, inter-security agency conflict has often resulted in the loss of lives and properties which extends to the civil populace. In the end, everybody becomes a casualty of inter-security agency skirmishes in the polity. This perhaps explains why Alemika (2003), Omoigui (2006), and Odoma (2014), in their separate studies, lamented that the inter-agency feud in Nigeria had exposed the country and her citizenry to perpetual threats, nightmares, and insecurity. More so, the ugly trend has dwarfed the giant status of Nigeria, because she is now regarded as an insecure and unsafe haven for foreign investments. Despite these acknowledged and obvious consequences of inter-security agency clashes in Nigeria, security analysts tend to gloss over exploring sustainable pathway to eliminating these seeming endless quarrels amongst the security agencies in Nigeria.

Abubakar (2017), this, however, does not compensate for the more serious cases of the Army's intolerance of media coverage of the insurgency. One such case was the decision made in 2014 to confiscate and destroy copies of several editions of newspapers across the country in which testimony to the Army's obsession with information control (ibid). For many days, soldiers seized and destroyed bundles of newspapers from at least ten media houses for 'security' reasons, but many regarded this action as a reprisal for the newspapers' coverage of their poor performance in the fight against Boko Haram (ibid). Civil society organizations and advocacy groups expressed dismay over the action. The Army's claims of receiving intelligence reports indicating movements of dangerous materials via newspaper distribution vehicles were never substantiated, and the anger of the newspapers' 
proprietors was never in doubt-the impulse to suppress criticism was unhelpful to the military's strategic communications efforts.

Communicators in such contexts are likely to be faced with unscrupulous, technologically adept adversaries and spoilers skilled in the latest communications techniques and willing to spread damaging lies and propaganda. Freedom of expression and a free media may be noticeable only by their absence, frequently necessitating additional work on media reform, regulation and development. Journalists can be targeted for assassination, as they have been in recent years in Iraq, Afghanistan, South Sudan, Somalia, Syria, Yemen, Libya and Nigeria. During or after a conflict, the rise of 'free' media aligned to political, religious and armed groups may bring dangerous issues such as hate-speech and incitement to violence to the fore, as witnessed in Nigeria over the years. Thus we can agree Nigerian government that illiteracy among the people with diverse cultural and ethnic background poses the problem of understanding one another in developmental objective designed by communication strategies. Misunderstanding and suspicion of each other's intention is more likely among people of different educational and literacy background.

\section{Summary and Conclusion}

Notwithstanding aforementioned challenges, there are prospects for institutionalizing and emplacing strategic communication in Nigeria. The military has shown a robust capacity to contribute to strategic communication research which informs policy and practice across government. According to office of the national security adviser ones said that effective and systemic use of strategic communication in all ministries, department and agencies is key to counter-terrorism and overall national security operations. The Armed Forces of Nigeria can scale up its non- kinetic approach through research in the use of strategic communication. This can begin by including strategic communication in the curriculum of our defence and Services training institutions. Furthermore, an effective Civil-Military Relations is relevant, more so in this era of asymmetric warfare. The models we build must necessarily be shaped by strategic communications doctrines that include cultural intelligence and conflict sensitive approaches by armed forces dealing with civilians in conflict. Also embarking on programmes or projects relevant to targeted communities could assuage minds and voices of dissenting individuals and hence boost Civil-Military Relations.

Interagency coordination and synchronization is a key challenge for security, defence and law enforcement agencies. Although we repeatedly highlight this challenge, few approaches to strengthen coordination have resulted in better synchronization among agencies. The use of strategic communications to integrate a new culture of communication among agencies 
can lead to greater efficiency in information and intelligence sharing. This could further be enhanced with the established Strategic Communication Inter - Agency Policy Coordination Committee. Similarly, the transnational nature of terrorists and use of internet requires a multi-stakeholder approach involving Governments, the ICT industry and civil society organizations in preventing and countering violent extremism online. This way the terrorists could be denied the freedom to exploit the internet for recruiting followers. This multistakeholder approach that combines political, technical, and contextual expertise is essential for both content- and communications-based responses.

This study concludes that the Nigerian Armed Forces and Boko Haram insurgents have engaged actively in strategic communications campaigns in pursuit of their goals and aims. The jihadists have succeeded in attracting global media attention, mainly by the sheer scale of their violence and their infamies, but also by the effective use of their communications strategies. The Army is at the forefront of Nigeria's effort to counter these strategies. It uses its formal communications structure and other methods to challenge their narratives and disrupt their media strategies. Although, the military has recorded some successes in containing the insurgents, largely because of the upper hand it has gained on the physical battlefield, but also because of waning media interest in the militants due to their diminishing capacity to stage headline-grabbing attacks. Therefore, there is the need to enhance our national values and identities through strategic communications. As a nation, we must develop our master narratives. Everyone who speaks for Nigeria must know and imbibe such positive narratives in their communication.

\section{References}

Abubakar, A T (2017), 'Audience Participation and BBC's Digital Quest in Nigeria'. In Everyday Media Culture in Africa: Audiences and Users, edited by W. Williams and W. Mano. Oxford: Routledge.

Aibieyi S (2014), "Approaches, Skills and Styles of Leadership in Organizations" Review of Public Administration and Management Vol. 3, No. 5.

Asaju, T (2015), 'Towards a Positive Army-media Relations'. Daily Trust. 2 August 2017. BBC. 'Nigeria's Sambo Dasuki charged over '\$68m fraud'. 14 December 2015, https://www.bbc.co.uk/news/amp/world-africa-35093785

Awosusi O E and Ogbuleke L E (2019), "Critical Thinking in Information Technology and Management for National Security in Nigeria" Asian Journal of Applied Science and Technology (AJAST) (Peer Reviewed Quarterly International Journal) Volume 3, Issue 3, Pages 41-52, July -September 2019 
Bellamy B Buzan People, State and Fear: An Agenda for International Security in Post cold War Era (Colorado: Reiner Publishers, 1991),

Berkovich, I. (2016). School leaders and transformational leadership theory: time to part ways? Journal of Educational Administration, 54(5), 609-622

Blanchard, K (2010), "Leading at a Higher Level" Upper Saddle River NJ: FT Press Castells M (2008), "Communication Power", Oxford OUP, 2008.

Clarke, S. (2013). Safety leadership: A meta-analytic review of transformational and transactional leadership styles as antecedents of safety behaviours. Journal of Occupational and Organizational Psychology, 86(1),

Cornish P (2011), Julian Lindley-French and Claire York, Strategic Communication and National Security, A Chatham House Report,

Coyle, Diane and Patrick Meier (2009) "New Technologies in Emergencies and Conflicts: The Role of Information and Social Networks" Washington D.C. and London U.K.: UN Foundation and Vodofone Partnership

Daily Trust. 'Armed Forces Launch Radio Station'. 24 May 2015, https://www.

dailytrust.com.ng/sunday/index.php/news/20798-armed-forces-launch-radio-station

Defination by US Public Affairs Operations, online available at

http://www.au.af.mil/info-ops/strategic.htm.

Eme, O I (2018), "Inter-Security Agency Rivalry as an Impediment to National Counter Terrorism Strategy (NACTEST)" AfriHeritage Research Working Paper

Frandsen, F., \& Johansen, W. (2017). Strategic communication. In C. R. Scott \& L. K. Lewis (Eds.), The international encyclopedia of organizational communication (pp. 2250-2258). Hoboken, NJ: Wiley-Blackwell

Hallahan, K., Holtzhausen, D., van Ruler, B., Verčič, D., \& Sriramesh, K. (2007). Defining strategic communication. International Journal of Strategic Communication, 1(1), 3-35. doi: $10.1080 / 15531180701285244$

Herskovits, J (2009), 'The Real Tragedy in Nigeria's Violence'. Foreign Policy. 3 August 2009, http://www.foreignpolicy.com/articles/2009/08/03/the_real_tragedy_in_nigerias_violence Imran Z et al (2012), 'Non-Kinetic Challenges to the State of Pakistan', National Strategy Paper, Institute for Strategic Studies, Research \& Analysis (ISSRA), National Defence University, Islamabad

James G.S (2007), Strategic Communication and National Security, ( National Defence University, USA. issue 46, 3d quarter 2007). 
Lixin J and Tahira M. P (2016) "Transformational and passive leadership as cross-level moderators of the relationships between safety knowledge, safety motivation, and safety participation" Journal of Safety Research 57 (2016) 27-32

Omorogbe SO, Oladele J K, Imhonopi D and Evbuoma IK (2016), "Good Governance and Leadership: Pathway to Sustainable National Development in

Nigeria"https://www.researchgate.net/publication/295399476_Good_Governance_and_Leader ship_Pathway_to_Sustainable_National_Development_in_Nigeria

Oyedijo, A. (1995). Principles of Management, Ibadan: Paramount Books Ltd.

Ribadu N (2013) "Leadership and National Development: The Missing Link"https://www.premiumtimesng.com/opinion/145502-leadership-national-development-mi ssing-link-nuhu-ribadu.html

Ribadu N, former anti-corruption czar for the country, delivered this speech at the Shell Club Port Harcourt Nigeria Independence Anniversary Celebration (NIAC) 2013 Lecture on September 26 Shinkaye J K (2004), "National Security and Challenges of the 21st Century", a lecture presented to the Participants of the National Institute for Policy and Strategic Studies, SEC 26, Kuru, Jos, 2004.

Sorensen, A. and Epps, R (1996), "Community Leadership and Local Development," Journal of Rural Studies

Tasiu Abubakar, A. (2017). Strategic communications, Boko Haram and counterinsurgency. Defence Strategic Communications, 3(Autumn), pp. 143.

The Nation (2017) 'Capture Shekau "Dead or Alive", Buratai Directs Commander'. 22 July 2017, http://thenationonlineng.net/capture-shekau-dead-alive-buratai-directscommander/

Thomas X. H (2007), The Message is the Insurgency: Strategic Communications in the Society at War, ( Marine Corps Gazette 91, Vol. 11, 2007)

Van Knippenberg, D., \& Sitkin, S. B. (2013). A critical assessment of charismatic Transformational leadership research: Back to the drawing board? The Academy of Management Annals, 7(1), 1-60.

Williams, John, 'Weaponised Honesty: Communication Strategy and NATO Values', Defence Strategic Communications, 2, (2017), p. 205 